\title{
Bermain Kognitif Matematika Anak Melalui Pemanfaatan Barang Bekas pada Masa Pandemi Covid-19
}

\author{
Suzana $^{1 *}$, Abdul Karim², Amanah ${ }^{3}$, Ahmad Munajim ${ }^{4}$ \\ 1,3,4 Institut Agama Islam Bunga Bangsa Cirebon, Indonesia \\ ${ }^{2}$ Universitas Muhammadiyah Cirebon, Indonesia
}

\section{ART ICLE INFO}

Article history:

Received 09 April 2021

Revised 10 April 2021

Accepted 05 Mei 2021

Available online 25 Agustus 2021

Kata Kunci:

Bermain Kognitif, Matematika, Barang Bekas

Keywords:

Cognitive Play, Math, Secondhand

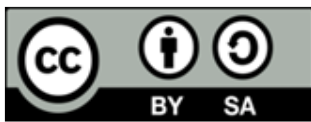

This is an open access article under the CC BY-SA license.

Copyright $(\subseteq 2021$ by Author. Published by Universitas Pendidikan Ganesha.

\begin{abstract}
A B S T R A K
Pembelajaran selama pandemic covid 19 dilakukan secara jarak jauh akan tetapi sebagian guru melakukan bimbingan terhadap siswa secara bergantian dikarenakan kendala koneksi internet yang kurang baik dan terlebih mobilitas orang tua siswa yang sebagian sibuk. Karena kendala tersebut, permasalahan yang ada adalah belum adanya peralatan yang cocok dalam rangka meningkatkan kemampuan kognitif anak. Oleh karena itu, tujuan penelitian ini adalah untuk mengidentifikasi sejauhmana hasil upaya kemampuan kognitif matematika anak melalui permainan membuat alat transportasi. Penelitian ini merupakan jenis penelitian tindakan kelas (PTK) yang dilaksanakan dengan model Kurt Lewin. Penelitian PTK dilaksanakan dalam2 siklus penelitian, dengan tahapan perencanaan, pelaksanaan tindakan, pengamatan dan refleksi pada setiap siklusnya. Subjek yang terlibat dalam penelitian ini yakni anak kelompok B1 di TK. Pengumpulan data dilakukan dengan menggunakan metode observasi yang kemudian dianalisis menggunakan teknik analisis deskriptif kuantitatif yaitu data yang diperoleh dalam bentuk presentase. Hasil analisis penelitian menunjukkan bahwa pada tahap prasiklus kemampuan kognitif matematika anak hanya mencapai $32,1 \%$ kemudian meningkat pada siklus I menjadi $66 \%$, dan meningkatkan kembali pada siklus II menjadi $92,2 \%$. Hasil yang diperoleh pada penelitian ini menunjukkan bahwa terdapat peningkatan kemampuan kognitif matematika ana di setiap siklusnya, sehingga dapat ditarik kesimpulan bahwa kemampuan kognitif matematika anak yang terkendala dengan koneksi internet dan kesibukan orang tua dapat ditingkatkan melalui pembelajaran menggunakan alat transportasi dari barang bekas.
\end{abstract}

\begin{abstract}
A B S T RA CT
Learning during the covid 19 pandemic was carried out remotely, but some teachers took turns guiding students due to poor internet connection constraints and especially the mobility of some of the students' parents who were busy. Because of these obstacles, the problem is that there is no suitable equipment in order to improve children's cognitive abilities. Therefore, the purpose of this study was to identify the extent to which children's mathematical cognitive ability efforts were made through the game of making means of transportation. This research is a type of classroom action research (CAR) which is carried out using the Kurt Lewin model. CAR research was carried out in 2 research cycles, with the stages of planning, implementing actions, observing and reflecting on each cycle. The subjects involved in this study were group B1 children in kindergarten. Data was collected using the observation method which was then analyzed using quantitative descriptive analysis techniques, namely the data obtained in the form of percentages. The results of the analysis showed that at the pre-cycle stage, children's mathematical cognitive abilities only reached $32.1 \%$, then increased in the first cycle to $66 \%$, and increased again in the second cycle to $92.2 \%$. The results obtained in this study indicate that there is an increase in children's mathematical cognitive abilities in each cycle, so it can be concluded that children's mathematical cognitive abilities who are constrained by internet connections and busy parents can be improved through learning to use transportation from used goods.
\end{abstract}




\section{PENDAHULUAN}

Anak usia dini merupakan individu yang menjalani proses pertumbuhan dan perkembangan yang sangat pesat dan fundamental bagi kehidupan selanjunya, sehingga proses pembelajaran anak usia dini harus memperhatikan karakteristik yang dimiliki setiap tahapan perkembangannya (Ashadi, 2017; Eldes, 2015). Rentang usia anak usia dini berada pada rentang usia golden age, yang merupakan usia dimana anak mulai mengembangkan kemampuannya dalam berbagai bidang, pada usia ini anak juga dikenalkan dengan berbagai hal dan fenomena yang terjadi di lingkungan dengan memanfaatkan benda-benda konkret (Juniati \& Hazizah, 2020; Khaironi, 2018). Untuk memaksimalkan perkembangan kemampuan anak usia dini, maka dibentuklah instansi pendidikan berupa PAUD dan Taman Kanak-Kanak (TK). Pada dasarnya Pendidikan Anak Usia Dini (PAUD) merupakan upaya pendidikan yang ditujukan kepada anak yang dilakukan melalui pemberian rangsangan pendidikan untuk membantu pertumbuhan dan perkembangan anak agar anak memiliki kesiapan untuk memasuki pendidikan yang lebih lanjut (Afriyeni, 2018; Eldes, 2015). Terdapat enam aspek yang akan dikembangkan dalam pendidikan anak usia dini, diantaranya adalah kognitif, fisik motorik, bahasa, sosial emosional, dan seni (Chanifudin \& Nuriyati, 2020; Sulaiman et al., 2019).

Salah satu aspek yang paling dominan dikembangkan yakni aspek kognitif, hal ini dikarenakan melalui pengembangan kemampuan kognitif anak akan mampu melakukan eksplorasi terhadap dunia sekitar melalui panca indranya (Fajriani \& Liana, 2020). Secara sederhana kognitif diartikan sebagai suatu proses berpikir yang berhubungan dengan tingkat kecerdasan anak (Suryaningsih \& Rimpiati, 2018). Sebagian besar aspek kemampuan kognitif ditentukan oleh manipulasi dan interaksi aktif anak dengan lingkungan yang diwujudkan dalam bentuk kemampuan untuk menghubungkan, menilai dan mempertimbangkan suatu kejadian atau peristiwa. Perkembangan kognitif anak dapat dilihat dari apa yang mereka lakukan atas dasar dorongan dan rasa ingin tahu yang besar (Novitasari, 2018). Upaya yang dapat dilakukan untuk mengembangkan kemampuan kognitif anak usia dini kususnya pada muatan matematika yakni dengan menyediakan berbagai media pembelajaran yang inovatif dan sesuai dengan karakteristik anak (Eldes, 2015; Kartini et al., 2020). Media pembelajaran merupakan teknologi pembawa pesan yang dapat dimanfaatkan untuk keperluan pembelajaran sehingga dapat mencapi tujuan pembelajaran dengan lebih baik (Liyana \& Kurniawan, 2019; Novitasari et al., 2021; C. N. Putri et al., 2019). Kegiatan pembelajaran anak usia dini cenderung berlangsung dalam situasi yang menyeluruh dan terkait dengan kehidupan sehari-hari sehingga memerlukan media pembelajaran yang sesuai dengan karakteristik dan kebutuhan anak.

Hanya saja dengan adanya pandemic covid-19 pelaksanaan pembelajaran dilakukan secara daring yang kemudian berakibat pada kurang maksimalnya kegiatan belajar mengajar anak usia dini. Penggunaan media cenderung hanya terbatas pada penggunaan media berupa video pembelajaran yang hanya dapat ditonton oleh siswa tanpa mampu dipraktekkan. Hal ini sejalan dengan hasil observasi di TK Negeri Pembina Kota Cirebon yang menunjukkan hasil bahwa guru masih kesulitan untuk mengontrol perkembangan keterampilan serta kemampuan kognitif anak. Guru hanya dapat bertemu dengan anak melalui proses tatap muka virtual yang dilaksanakan 2x dalam seminggu. Kurangnya kemampuan guru dalam menciptakan proses pembelajaran yang bermakna di masa pandemic seperti saat ini, berdampak pada rendahnya kemapuan kognitif anak kususnya pada mata pelajaran matematika.

Salah satu upaya yang dapat dilakukan untuk mengatasi permasalahan tersebut yakni dengan mengajak anak untuk belajar sambil bermain. Kegiatan bermain dapat dilakukan dengan menggunakan media bahan bekas yang ada di sekitar anak. Barang bekas diartikan sebagai suatu barang yang tidak dapat dipergunakan lagi dan berasal dari sisa-sisa sampah rumah tangga maupun sisa-sisa dari pabrik (Putri \& Pransiska, 2021; Siron et al., 2020). Berdasarkan pengertian barang bekas, dapat diketahui bahwa media barang bekas merupakan alat yang digunakan dalam kegiatan pembelajaran yang berasal dari segala sesuatu yang tertinggal atau sudah tidak digunakan lagi, namun masih dapat digunakan menjadi barang baru yang lebih bernilai guna (Faishol et al., 2021; Jannah \& Pratiwi, 2021). Barang bekas yang dapat dimanfaatkan kembali sebagai media pembelajaran merupakan barang bekas yang berbahan dasar plastik, kaleng, kertas, dan kardus. Benda tersebut dapat dimanfaatkan menjadi sebuah benda yang memiliki daya guna yang tinggi dan dapat membantu proses beajar anak. Selain dapat meningkatkan kemampuan kognitif anak penggunaan barang bekas juga dapat meningatkan karakter peduli lingkungan dan membiasakan anak untuk selalui menjaga kebersihan (Humairah et al., 2021).

Beberapa penelitian yang berkaitan dengan penggunaan barang bekas sebagai media pembelajaran menyatakan bahwa pemanfaatan media barang bekas dalam kegiatan pembelajaran mampu meningkatkan kemampuan motorik halus anak usia dini, dimana dalam setiap melakukan kegiatan semua aktivitas motorik halus anak bekerja dan berkembang sangat baik (BSB) pada hasil akhir (Maghfirah, 2019). Penelitian lainnya juga menyebutkan bahwa barang bekas dapat dijadikan sebagai media peningkatan kreativitas siswa baik secara motorik maupun kognitif, hal ini dikrenakan media barang 
bekas mampu mengembangkan sebuah hasil karya menurut pemikiran dan imajinasi mereka sendiri (Agustina et al., 2018). Selain dapat meningkatkan kemampuan kognitif serta kreatifitas anak, penggunaan media barang bekas juga memberikan dampak positif pada peningkatan motivasi dan semangat belajar siswa (Pambudi et al., 2019). Berdasarkan pemaparan hasil penelitian terdahulu dapat dikatakan bahwa media barang bekas sangat efektif digunakan sebagai media pembelajaran karena dapat meningkatkan kemampuan kognitif, meningkatkan keterampilan, serta meningkatkan motivasi belajar anak. Hanya saja pada penelitian sebelumnya belum terdapat kajian mengenai penggunaan media barang bekas, sehingga penelitian ini difokuskan pada peningkatan kemampuan kognitif menggunakan media barang bekas dengan tujuan untuk mengidentifikasi sejauhmana hasil upaya kemampuan kognitif matematika anak melalui permainan membuat alat transportasi.

\section{METODE}

Penelitian ini merupakan jenis penelitian tindakan kelas kelas (PTK) yang dilaksanakan dalam 2 siklus penelitian. Setiap siklus penelitian terdiri atas 4 tahapan yakni tahap perencanaan, pelaksanaan tindakan, pengamatan dan refleksi. Tahap perencanaan dalam penelitian ini adalah penyiapan materi dan bahan ajar, pembuatan rencana pembelajaran yang mencakup metode dan media. Rancangan pelaksanaan penelitian dapat dilihat pada gambar 1 .

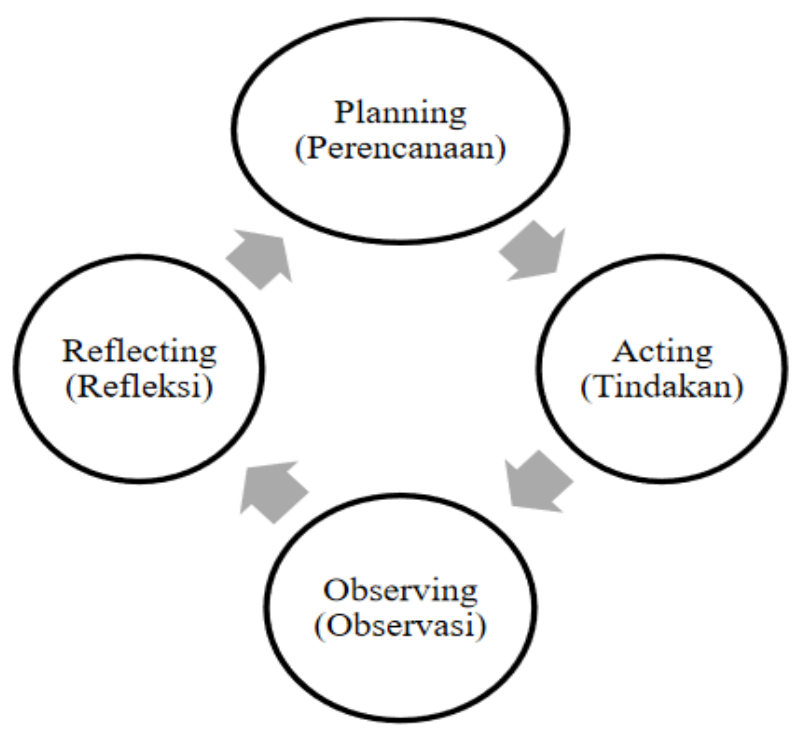

Gambar 1. Model Penelitian Tindakan Spiral Kurt Lewin

Pada siklus 1 peneliti membuat perencanaan dengan membuat Rencana Pelaksanaan Pembelajaran Mingguan (RPPM) dan membuat Rencana Pelaksanaan Pembelajaran Harian (RPPH) dengan tema kendaran sub teme kendaraan di air, dengan su-sub tema Perahu dan rakit, membuat perencanaan penilaian. Melakukan observasi langsung dan pencatatan hasil peningkatan kemampuan kognitif matematik anak terhadap permainan membuat alat transportasi. Data-data yang diperoleh melalui observasi dikumpulkan dan dianalisis untuk mengetahui perubahan yang diperoleh dari hasil tindakan. Adapun kisi-kisi observasi dapat dilihat pada tabel 1 dan 2.

Tabel 1. Kisi-Kisi Observasi Aktivitas Anak

\begin{tabular}{|c|c|c|c|}
\hline No & Aspek yang Diamati & Indikator & Penilaian \\
\hline 1 & Keaktifan & $\begin{array}{l}\text { a. ktif bertanya tentang alat } \\
\text { transportasi } \\
\text { b. Beraktifitas mandiri pada } \\
\text { saat permainan membuat } \\
\text { alat transportasi } \\
\text { c. Pro aktif terhadap tanggung } \\
\text { jawab terhadap tugas } \\
\text { membuat alat transportasi } \\
\text { dengan rapih }\end{array}$ & $\begin{array}{l}\text { 1. BB: Belum berkembang (Jika } \\
\text { tidak terdapat indikator) } \\
\text { 2. MB: Mulai Berkembang (Jika } \\
\text { terdapat } 1 \text { indikator) } \\
\text { 3. BSH: Berkembang sesuai } \\
\text { harapan (Jika terdapat } 2 \\
\text { indikator) } \\
\text { 4. BSB: Berkembang sangat baik } \\
\text { (Jika terdapat semua indikator) }\end{array}$ \\
\hline
\end{tabular}




\begin{tabular}{|c|c|c|c|}
\hline No & Aspek yang Diamati & Indikator & Penilaian \\
\hline 2 & Keberanian & $\begin{array}{l}\text { a. Berani bertanya tentang alat } \\
\text { dan media permainan alat } \\
\text { transportasi } \\
\text { b. Berani tampil di depan kelas } \\
\text { dan berani tampil ketika } \\
\text { zoom atau pembelajaran } \\
\text { jarak jauh } \\
\text { c. Berani mununjukkan } \\
\text { inisiatif dalam memilih } \\
\text { permainan alat transportasi }\end{array}$ & $\begin{array}{l}\text { 1. BB: Belum berkembang (Jika } \\
\text { tidak terdapat indikator) } \\
\text { 2. MB: Mulai Berkembang (Jika } \\
\text { terdapat } 1 \text { indikator) } \\
\text { 3. BSH: Berkembang sesuai } \\
\text { harapan (Jika terdapat } 2 \\
\text { indikator) } \\
\text { 4. BSB: Berkembang sangat baik } \\
\text { (Jika terdapat semua indikator) }\end{array}$ \\
\hline
\end{tabular}

Tabel 2. Kisi-Kisi Penilaian Kemampuan Kognitif Matematika Anak

\begin{tabular}{|c|c|c|c|}
\hline No & Aspek yang Diamati & Indikator & Penilaian \\
\hline 1 & $\begin{array}{c}\text { Mengenal warna dan } \\
\text { bagian-bagian pada } \\
\text { alat transportasi }\end{array}$ & $\begin{array}{l}\text { a. Anak mampu mengenal } \\
\text { bagian bagian alat } \\
\text { transportasi } \\
\text { b. Anak mampu mengenal fungsi } \\
\text { alat transportasi } \\
\text { c. Anak mampu mengenal } \\
\text { warna pada gambar alat } \\
\text { transportasi }\end{array}$ & $\begin{array}{l}\text { 1. BB: Belum berkembang (Jika } \\
\text { tidak terdapat indicator) } \\
\text { 2. MB: Mulai Berkembang (Jika } \\
\text { terdapat } 1 \text { indikator) } \\
\text { 3. BSH: Berkembang sesuai } \\
\text { harapan (Jika terdapat } 2 \\
\text { indikator) } \\
\text { 4. BSB: Berkembang sangat baik } \\
\text { (Jika terdapat semua indicator) }\end{array}$ \\
\hline 2 & Konsep bilangan & $\begin{array}{l}\text { a. Anak mampu mengenal } \\
\text { lambing bilangan pada } \\
\text { gambar alat transportasi } \\
\text { b. Anak mampu mengoprasikan } \\
\text { penjumlahan sederhana } \\
\text { dengan gambar alat } \\
\text { transportasi } \\
\text { c. Anak mampu mengoprasikan } \\
\text { konsep pengurangan } \\
\text { sederhana pada gambar alat } \\
\text { transportasi }\end{array}$ & $\begin{array}{l}\text { 1. BB: Belum berkembang (Jika } \\
\text { tidak terdapat indikator) } \\
\text { 2. MB: Mulai Berkembang (Jika } \\
\text { terdapat } 1 \text { indikator) } \\
\text { 3. BSH: Berkembang sesuai } \\
\text { harapan (Jika terdapat } 2 \\
\text { indikator) } \\
\text { 4. BSB: Berkembang sangat baik } \\
\text { (Jika terdapat semua indikator) }\end{array}$ \\
\hline 3 & $\begin{array}{l}\text { Pengukuran banyak } \\
\text { sedikit, panjang } \\
\text { pendek, besar kecil }\end{array}$ & $\begin{array}{l}\text { a. Anak mampu megukur } \\
\text { perbedaan banyak sedikit } \\
\text { pada gambar alat transportasi } \\
\text { b. Anak mampu mengukur } \\
\text { perbedaan tinggi pendek } \\
\text { dengan menggunakan } \\
\text { sedotan }\end{array}$ & $\begin{array}{l}\text { 1. BB: Belum berkembang (Jika } \\
\text { tidak terdapat indicator) } \\
\text { 2. MB: Mulai Berkembang (Jika } \\
\text { terdapat } 1 \text { indikator) } \\
\text { 3. BSH: Berkembang sesuai } \\
\text { harapan (Jika terdapat } 2 \\
\text { indikator) } \\
\text { 4. BSB: Berkembang sangat baik } \\
\text { (Jika terdapat semua indikator) }\end{array}$ \\
\hline
\end{tabular}

Pada siklus 2 peneliti membuat perencanaan dengan membuat Rencana Pelaksaaan Pembelajaran Mingguan (RPPM) dan membuat Rencana Pelaksaan Pembelajaran Harian (RPPH) dengan tema kendaraan, sub tema, kendaraan udara, dan sub-sub tema helicopter dan balon udara, membuat perencanaan penilaian. Melakukan tindakan pembelajaran melalui pembuatan video yang menarik bagi anak-anak dan bimbingan belajar. Melakukan observasi langsung dan pencatatan hasil peningkatan kemampuan kognitif matematika anak terhadap permainan membuat alat transportasi. Data-data yang diperoleh melalui observasi dikumpulkan dan dianaliss untuk mengetahui perubahan yang diperoleh dari hasil tindakan.

Subjek dalam penelitian adalah anak kelompok B1 di TK Negeri Pembina Kota Cirebon. Pengumpulan data dalam peneltian dilakukan dengan menggunakan teknik observasi dengan mencatat seluruh data yang dilihat dari perilaku dan kondisi anak selama sebelum dan sesudah melakukan tindakan di TK Negeri Pembina Kota Cirebon. Dokumentasi berupa catatan hasil peningkatan perkembangan anak baik secara tulisan atau elekrtonik. Instrumen pengumpulan data menggunakan lembar evaluasi anak didik dan keaktifan anak dalam merespon dan melakukan kegiatan yang diberikan melalui video 
pembelajaran dan bimbingan belajar. Data yang diperoleh kemudian dianalisis dengan menggunakan tekhnik analisis deskriptif kuantitatif. Hasil analisis data kemudian disajikan dalam bentuk persentase dengan kategori persentase dapat dilihat pada tabel 3.

Tabel 3. Skala Interpretasi persentase

\begin{tabular}{cc}
\hline Persentase & Kategori \\
\hline $80 \%-100 \%$ & Sangat baik \\
$60 \%-79 \%$ & Baik \\
$40 \%-59 \%$ & Cukup \\
$20 \%-39 \%$ & Rendah / Kurang baik \\
$0 \%-19 \%$ & Sangat Rendah \\
\hline
\end{tabular}

\section{HASIL DAN PEMBAHASAN}

Hasil

Penelitian tindakan kelas mengenai aktifitas guru dalam kegiatan bermain kognitif matematika menggunakan barang bekas diawali dengan tahap penelitian prasiklus. Pada tahap pra siklus diketahui bahwa guru masih belum maksimal dalam melakukan upaya peningkatan kognitif anak, hal ini ditunjukkan dengan hasil persentase yang hanya mencapai 58,3\% dengan kategori cukup. Untuk meningkatkan aktifitas guru dalam kegiatan pembelajaran penelitian dilanjutkan pada tahap siklus I. Pada siklus I Guru membuat perencanaan pembelajaran yang berpusat pada kebutuhan anak, media pembelajaran berupa kardus bekas, lem, spidol, dll yang dibutuhkan sebagai alat permainan edukatif anak disiapkan sesuai jumlah anak didik. Guru melakukan pengelolaan kelas dan pemilihan strategi pembelajaran yang menyenangkan di kelas. Pada akhir pembelajaran guru melakukan tanya jawab sebagai umpan balik dari anak atas proses kegiatan bermain sambil belajar sebagai bahan untuk evaluasi dan refleksi pada siklus selanjutnya. Hasil yang diperleh pada Siklus I menunjukkan adanya peningkatan aktifitas guru dari 58,3\% menjadi 76,6 \% yang termasuk kedalam kategori Baik. Hanya saja hasil yang diperoleh pada siklus I masih belum maksimal dan perlu ditingkatkan lagi, dengan refleksi: melakukan perbaikan pada perencanaan pembelajaran (RPPH), memberi kesempatan pada anak satu persatu untuk bertanya mengenai hal-hal yang belum dimengerti tentang konsep kognitif yang diajarkan, memberi motivasi pada anak agar lebih antusias dan tidak malu dalam mengungkapkan pendapatnya menjawab pertanyaan, mengajak anak untuk menyimpulkan hasil pembelajaran secara bersama sebagai penguatan terhadap pengetahuan yang telah diterima, serta memberi penghargaan barupa kalimat pujian pada anak yang telah mampu melaksanakan kegiatan sesuai arahan.

Hasil refleksi pada siklus I kemudian diterapkan pada siklus II , sehingga pada siklus II terjadi aktifitas guru menjadi 83,8 \% termasuk kategori sangat baik, hal ini merupakan upaya perbaikan yang dilakukan guru baik dari perencanaan, pelaksanaan pembelajaran di kelas hingga penutup berdasarkan refleksi dari siklus I. Peningkatan aktifitas guru pada tahap pra siklus sampai siklus II dapat dilihat pada tabel 4.

Tabel 4. Rekapitulasi Aktifitas Guru

\begin{tabular}{ccccc}
\hline $\mathbf{N}=\mathbf{2}$ & Rata-Rata & $\mathbf{( \% )}$ & Interp. & Kategori \\
\hline Pra Siklus & 0,583 & 58,3 & $\mathrm{C}$ & Cukup \\
Siklus I & 0,766 & 76,6 & $\mathrm{~B}$ & Baik \\
Siklus II & 0,833 & 83,3 & SB & Sangat baik \\
\hline
\end{tabular}

Selain dilakukan penelitian untuk mengetahui peningkatan aktifitas guru pada setiap siklusnya, penelitian juga dilakukan untuk mengetahui peningkatan kemampuan kognitif matematika siswa. Berdasarkan hasil penelitian pada tahap prasiklus didapatkan hasil bahwa kemampuan kognitif anak pada pra siklus hanya mencapai persentase rata-rata 32,1 \% dengan kategori kurang baik. Rendahnya kemampuan kognitif matematika anak disebabkan karena masih banyak anak yang kurang mengenal warna dan bagian-bagian alat transportasi, anak masih rendah dalam mengoprasikan konsep penjumlahan dan pengurangan serta belum dapat membedakan antara tinggi pendek-banyak sedikitbesar kecil. Untuk mengatasi hal tersebut maka penelitian dilanjutkan pada siklus I.

Kegiatan pembelajaran pada siklus I dilakukan pada tema kendaraan, dengan menggunakan permainan membuat alat transportasi yang bertujuan untuk meningkatkan kemampuan kognitif matematika anak, seperti anak mampu mengenal warna, mengenal bagian-bagian alat transportasi, mengenal konsep bilangan dan dapat mebedakan antara tinggi pendek, banyak sedik, dan besar kecil. 
Hasil yang diperoleh pada pembelajaran siklus I menunjukkan adanya peningkatan kemampuan kognitif anak yang awalnya hanya 32,1\% meningkat menjadi 66\%. Hanya saja hasil yang diperoleh pada siklus I masih belum maksimal dan masih terdapat beberapa kekurangan dalam pelaksanaannya seperti tidak semua siswa bisa aktif dalam kegiatan belajar, kegiatan belajar masih didominasi oleh orang tua, serta tidak semua anak memahami cara membuat karya dengan baik. Sehingga untuk mengatasi kekurangan kekurangan tersebut kegiatan pembelajaran kemudian dilanjutkan pada siklus II.

Kegiatan pada siklus II masih menggunakan tema kendaraan dengan tujuan meningkatkan kemampuan kognitif matematika anak. Dalam pembeajaran siklus II telah terjadi peningkatan aktivitas belajar dan kemampuan kognitif anak. Hal ini ditunjukkan adanya peningkatan persentase kamampuan kognitif yang telah mencapai 92,25\% dengan kategori sangat baik. Rincian mengenai peningkatan kemampuan kognitif siswa dari tahap prasiklus sampai pada siklus II dapat dilihat pada tabel 5.

Tabel 5. Rekapitulasi Kemampuan Kognitif Anak pada Pra Siklus

\begin{tabular}{ccccc}
\hline N = 14 & Rata-Rata & (\%) & Interp. & Kategori \\
\hline Pra Siklus & & & & \\
A & 1,3 & 32,1 & KB & \\
B & 1,1 & 26,8 & KB & $32,1=\mathrm{KB}$ \\
C & 1,9 & 46,4 & CB & \\
Siklus I & 2,7 & 67,9 & & \\
A & 2,3 & 58,9 & CB & $66=$ B \\
B & 2,9 & 73,2 & B & \\
C & & & & \\
Siklus II & 3,6 & 89,2 & SB & \\
A & 3,5 & 87,5 & SB & $92,2=$ SB \\
B & 4 & 100 & SB & \\
C & & & &
\end{tabular}

Keterangan Indikator:

A : Mengenal warna dan bagian-bagian alat transportasi

B : Konsep bilangan

C : Pengukuran banyak sedikit, panjang pendek, besar kecil.

\section{Pembahasan}

Berdasarkan analisis hasil penelitian, didapatkan informasi bahwa terdapat peningkatan kemampuan kognitif siswa dari tahap pra siklus sampai siklus II. Peningkatan kemampuan kognitif ini tidak terlepas dari penggunaan barang bekas sebagai media pembelajaran. Kegiatan pembeajaran dilaksanakan melalui proses pendidikan yang merupakan proses kehidupan dan bukan penyiapan kehidupan dimasa yang akan datang, maka pekerjaan guru akan sangat penting dan bernilai apabila yang dilakukan guru tidak hanya mengajarkan materi pembelajaran, melainkan bagaimana menjalani kehidupan, dengan demikian kegiatan bermain memanfaatan barang bekas menjadi media pembelajaran yang inofatif dan menyenangkan menambah pengalaman langsung anak, bukan hanya sekedar materi melainan proses pengalaman yang nyata akan mudah dipahami oleh anak (Sugrah, 2020). Untuk menciptakan proses pembelajaran yang bermakna maka dibutuhkan suatu media pembelajaran yang paraktis dan inovatif sesuai dengan karakteristik anak usia dini.

Salah satu media yang dianggap sesuai yakni media barang bekas. Barang bekas merupakan barang habis pakai yang sudah tidak digunakan lagi (Kurniawan, 2019; Setyowati, 2021). Hanya saja barang bekas ini dapat diolah menjadi suatu barang baru yang memiliki nilai guna tinggi. Penggunaan barang bekas sebagai media pembelajaran akan memberikan kemudahan kepada guru maupun siswa, hal ini dikarenakan barang bekas sangat mudah ditemui dan dalam proses pembuatan medianya tidak membutuhkan biaya yang mahal. Media barang bekas diyakini dapat meningkatkan kemampuan kognitif anak usia dini, hal ini dikarenakan kemampuan kognitif merupakan salah satu aspek perkembangan yang sangat penting untuk mendukung tumbuh kembang anak dalam berfikir (Dewi, 2020; Kurniawati \& Atmojo, 2017). Perkembangan kognitif dapat distimulasi melalui bermain dan mengeksplorasi lingkungannya. Salah satu aspek yang penting dari kognitif yaitu berfikir kritis dan pemecahan masalah, berfikir kritis artinya anak mampu untuk mengetahui konsep, memahami dan menilai hal-hal yang sama atau berbeda dengan yang seharusnya, mampu menggali apa yang dilihat dan didengar (Ngurahrai et al., 2019). Anak memiliki kemampuan untuk memecahkan masalah yang ditemui dalam konteks sesuai dengan tugas perkembangan usianya. Salah satu upaya untuk meningkatkan minat anak dalam belajar adalah melaui bermain, beroirientasi pada kebutuhan anak, lingkungan yang kondusif,menggunakan 
pembelajaran terpadu, mengembangkan berbagai kecakapan hidup, menggunakan media edukatif dan sumber belajar, dilaksanakan secara bertahap (Suzana et al., 2020).

Matematika merupakan pelajaran yang memuat tentang bilangan, bentuk dan jumlah, sedangkan bilangan adalah sesuatu yang digunakan untuk menujukkan kuantitas (banyak dan sedikit) dan ukuran (berat, ringan, panjang, pendek) (Putri \& Dewi, 2020). Bilangan digambarkan dengan suatu tanda atau lambang yang disebut angka. Anak usia dibawah 7 tahun menggunakan konsep berantai dalam mempelajari matematika seperti memilah balok yang berbeda ukuran, warna, dan bentuk. Hasil yang diperoleh dalam penelitian ini sejalan dengan hasil yang diperoleh oleh peneliti sebelumnya, dimana pada penelitian sebeumnya juga disebutkan bahwa pemanfaatan media barang bekas dalam kegiatan pembelajaran mampu meningkatkan kemampuan motorik halus anak usia dini, dimana dalam setiap melakukan kegiatan semua aktivitas motorik halus anak bekerja dan berkembang sangat baik (BSB) pada hasil akhir (Maghfirah, 2019). Penelitian lainnya juga menyebutkan bahwa barang bekas dapat dijadikan sebagai media peningkatan kreativitas siswa baik secara motorik maupun kognitif, hal ini dikrenakan media barang bekas mampu mengembangkan sebuah hasil karya menurut pemikiran dan imajinasi mereka sendiri (Agustina et al., 2018). Selain dapat meningkatkan kemampuan kognitif serta kreatifitas anak, penggunaan media barang bekas juga memberikan dampak positif pada peningkatan motivasi dan semangat belajar siswa (Pambudi et al., 2019). Berdasarkan penelitian tersebut dapat diketahui bahwa media barang bekas sangat efektif digunakan untuk meningkatkan kemampuan kognitif serta meningkatkan kemampuan motorik anak. Penelitian ini dapat memberikan implikasi sosial berupa pengurangan resiko akibat barang berkas yang bisa mengakibatkan bencana alam seperti penumpukan sampah dan banjir. Adapun implikasi keilmuan bahwa media permainan bisa dibuat dari barang bekas dengan biaya yang jauh lebih murah daripada peralatan yang canggih dan modern yang justru tidak terjangkau bagi kalangan siswa tertentu.

\section{SIMPULAN}

Berdasarkan hasil dan pembahasan di atas dapat ditarik kesimpulan bahwa kemampuan kognitif matematika anak yang terkendala dengan koneksi internet dan kesibukan orang tua dapat ditingkatkan melalui pembelajaran menggunakan alat transportasi dari barang bekas. Persentase rata-rata kemampuan kognitif matematika anak sebelum tindakan ditemukan dalam keadaan kemampuan rata-rata anak belum berkembang, setelah diadakan tindakan dengan dua siklus kemudian kognitif siswa terus mengalami peningkatan dengan keadaan anak berkembang dengan baik, dan anak-anak berkembang sangat baik.

\section{DAFTAR RUJUKAN}

Afriyeni, Y. (2018). Pembentukan karakter anak untuk peduli lingkungan yang ada di sekolah Adiwiyata Mandiri SDN 6 Pekanbaru. PAUD Lectura: Jurnal Pendidikan Anak Usia Dini, 1(2), 123-133. https://doi.org/https://doi.org/10.31849/paudlectura.v1i2.1171.

Agustina, S., Nasirun, M., \& Delrefi. (2018). Meningkatkan Keterampilan Motorik Halus Anak Melalui Bermain dengan Barang Bekas. Jurnal Ilmiah Potensia, 3(1), 24-33. https://doi.org/10.33369/jip.3.1.24-33.

Ashadi, F. (2017). Pengembangan sumberdaya manusia dalam lembaga pendidikan anak usia dini. Jurnal Pembelajaran Fisika, 5(4), 412-418. https://jurnal.unej.ac.id/index.php/JPF/article/view/4448.

Chanifudin, \& Nuriyati, T. (2020). Integrasi Sains dan Islam dalam Pembelajaran. Asatiza: Jurnal Pendidikan, 1(2), 212-229. https://doi.org/10.46963/asatiza.v1i2.77.

Dewi, I. A. P. R. N. (2020). Pengembangan Media Flashcard Untuk Meningkatkan Kemampuan Mengenal Warna Pada Anak Usia Dini. Journal for Lesson and Learning Studies, 3(3), 49-59. https://doi.org/10.24127/j-sanak.v2i01.384.

Eldes, I. (2015). Ilmu Dan Hakekat Ilmu Pengetahuan Dalam Nilai Agama. Al-Hikmah, 9(2). https://doi.org/10.24260/al-hikmah.v9i2.322.

Faishol, R., Meliantina, M., Ramiati, E., Putri, E. I. E., \& Rahayu, S. M. (2021). Pendampingan Kegiatan Pembelajaran Siswa Dengan Memanfaatkan Barang Bekas Untuk Meningkatkan Minat Dan Kreativitas Belajar Pada Masa Pandemi Covid-19. ABDI KAMI: Jurnal Pengabdian Kepada Masyarakat, 4(1), 092. https://doi.org/10.29062/abdi_kami.v4i1.519.

Fajriani, K., \& Liana, H. (2020). Upaya Meningkatkan Kemampuan Kognitif Anak Usia 5-6 Tahun Melalui Permainan Pencampuran Warna Dengan Percobaan Sains Sederhana Di Tk Islam Silmi Samarinda. Pendas Mahakam: Jurnal Pendidikan Dasar, 4(1), 32-41. https://doi.org/10.24903/pm.v4i1.394. 
Humairah, Khamidah, Z., Rismawanda, R., Saud, A. S., \& Mubarok. (2021). Pemanfaatan Barang Bekas Sebagai Media Pembalajaran RAPATJURANG (Cara Cepat Penjumlahan dan Pengurangan). JAMU : Jurnal Abdi Masyarakat UMUS, 2(1). https://doi.org/https://doi.org/10.46772/jamu.v1i02.487.

Jannah, N. R., \& Pratiwi, W. (2021). Pendampingan Kegiatan Belajar Siswa dengan Memanfaatkan Barang Bekas untuk Meningkatkan Minat dan Kreativitas Belajar Siswa pada Era Covid-19. Bulletin of Community Engagement, 1(1), 1-6. https://attractivejournal.com/index.php/bce/article/ view/232/166.

Juniati, W., \& Hazizah, N. (2020). Pengaruh Permainan Sorting Color Dalam Meningkatkan Kemampuan Klasifikasi Pra-Matematika Di Taman Kanak-Kanak Islam Budi Mulia. Jurnal Golden Age, 4(1). https://doi.org/https://doi.org/10.29408/goldenage.v4i01.2187.

Kartini, K., Degeng, I. N. S., \& Sitompul, N. C. (2020). Pengembangan multimedia interaktif tema binatang untuk pembelajaran di taman kanak-kanak. Jurnal Inovasi Teknologi Pendidikan, 7(2), 128-139. https://doi.org/10.21831/jitp.v7i2.33879.

Khaironi, M. (2018). Perkembangan Anak Usia Dini. Jurnal Golden Age, 2(01), 01. https://doi.org/10.29408/goldenage.v2i01.739.

Kurniawan, E. Y. (2019). Pendidikan Berbasis Kreativitas Pada Mahasiswa PGPAUD Melalui Pemanfaatan Media Barang-Barang Bekas Dalam Pembelajaran Musik Perkusi di Universitas Muhammadiyah Tangerang. Ceria: Jurnal Program Studi Pendidikan Anak Usia Dini, 7(2), 1. https://doi.org/10.31000/ceria.v9i2.1272.

Kurniawati, W., \& Atmojo, S. E. (2017). Pembelajaran Sains Bermuatan Karakter Ilmiah Dengan Alat Peraga Barang Bekas Dan Asesmen Kinerja. JPI (Jurnal Pendidikan Indonesia), 6(1). https://doi.org/10.23887/jpi-undiksha.v6i1.8866.

Liyana, A., \& Kurniawan, M. (2019). Speaking Pyramid sebagai Media Pembelajaran Kosa Kata Bahasa Inggris Anak Usia 5-6 Tahun. Jurnal Obsesi: Jurnal Pendidikan Anak Usia Dini, 3(1), 225. https://doi.org/10.31004/obsesi.v3i1.178.

Maghfirah, S. (2019). Pemanfaatan Barang Bekas dalam Meningkatkan Kemampuan Motorik Halus Anak. Ațālunā: Journal of Islamic Early Childhood Education, 2(1), 48-52. https://doi.org/10.32505/atfaluna.v2i1.938.

Ngurahrai, A. H., Fatmaryanti, S. D., \& Nurhidayati, N. (2019). Pengembangan Media Pembelajaran Fisika Berbasis Mobile Learning Untuk Meningkatkan Kemampuan Berpikir Kritis Peserta Didik. Radiasi : Jurnal Berkala Pendidikan Fisika, 12(2), https://doi.org/10.37729/radiasi.v12i2.55.

Novitasari, Y. (2018). Analisis Permasalahan "Perkembangan Kognitif Anak Usia Dini". PAUD Lectura: $\begin{array}{lllll}\text { Jurnal Pendidikan Anak } & \text { 82-90. }\end{array}$ https://doi.org/10.31849/paudlectura.v2i01.2007.

Novitasari, Y., Prastyo, D., Iftitah, S. L., Reswari, A., \& Fauziddin, M. (2021). Media Daur Ulang (Recycle System) dalam Kemampuan Membaca Bahasa Inggris Awal Anak Usia Dini. Jurnal Pendidikan Anak Usia Dini, 6(3). https://doi.org/10.31004/obsesi.v6i3.1209.

Pambudi, B., Efendi, R. B., Novianti, L. A., Novitasari, D., \& Ngazizah, N. (2019). Pengembangan Alat Peraga IPA dari Barang Bekas untuk Meningkatkan Motivasi Belajar dan Pemahaman Siswa Sekolah Dasar. Indonesian Journal of Primary Education, 2(2), 28. https://doi.org/10.17509/ijpe.v2i2.15097.

Putri, A. Y., \& Dewi, S. (2020). Stimulasi Kemampuan Mengenal Konsep Bilangan Anak Usia Dini Melalui Permainan Matematika Montessori. Jurnal Pendidikan Tambusai, 21(1), 1-9. https://jptam.org/index.php/jptam/article/view/489.

Putri, C. N., Sofia, A., \& Drupadi, R. (2019). Pengembangan Keterampilan Berbahasa Anak Usia Dini Melalui Bermain Kartu Scrapbook. Jurnal Pendidikan Anak, 5(1), 63-65. https://doi.org/10.15900/j.cnki.zylf1995.2018.02.001.

Putri, W. M., \& Pransiska, R. (2021). Pembelajaran Dengan Kegiatan Daur Ulang Botol Bekas Untuk Anak Usia Dini. Edukatif: Jurnal Ilmu Pendidikan, 3(1), 144-148. https://doi.org/10.31004/ edukatif.v3i1.269.

Setyowati, C. (2021). Meningkatkan Kreativitas Anak melalui Media Bahan Bekas. Journal Ashil: Jurnal Pendidikan Anak Usia Dini, 1(1). https://doi.org/https://doi.org/10.33367/piaud.v1i1.1696.

Siron, Y., Khonipah, I., \& Fani, N. K. M. (2020). Penggunaan Barang Bekas Untuk Media Pembelajaran Di Paud: Pengalaman Guru. Early Childhood: Jurnal Pendidikan, 4(2), 63-74. https://doi.org/10.35568/earlychildhood.v4i2.868.

Sugrah, N. U. (2020). Implementasi teori belajar konstruktivisme dalam pembelajaran sains. Humanika, 19(2), 121-138. https://doi.org/10.21831/hum.v19i2.29274. 
Sulaiman, U., Ardianti, N., \& Selviana, S. (2019). Tingkat Pencapaian Pada Aspek Perkembangan Anak Usia Dini 5-6 Tahun Berdasarkan Strandar Nasional Pendidikan Anak Usia Dini. Nanaeke: Indonesian Journal of Early Childhood Education, 2(1), 52. https://doi.org/10.24252/nananeke.v2i1.9385.

Suryaningsih, A., \& Rimpiati, N. L. (2018). Implementation of Game-Based Thematic Science Approach in Developing Early Childhood Cognitive Capabilities. Jurnal Obsesi : Jurnal Pendidikan Anak Usia Dini, 2(2), 194. https://doi.org/10.31004/obsesi.v2i2.113.

Suzana, S., Munajim, A., Casta, C., Pratama, G., Sulaeman, E., Sukarnoto, T., Ridwan, M., \& Karim, A. (2020). Gadget And The Internet For Early Childhood Distance Learning. PalArch's Journal of Archaeology of Egypt/Egyptology, 17(7), 8019-8028. 